\title{
Development of Mathematical Learning Test For Student Groups With Linguistic Intelligence
} \author{
edipriobaskoro@syekhnurjati.ac.id

\section{a r t i c l ein fo} \\ How to cite this article: \\ Aqidah, N. Baskoro, E.D., Manfaat, B. (2019). \\ Development of Mathematical Learning Test For \\ Student Groups With Linguistic Intelligence. \\ Eduma : Mathematics Education Learning And \\ Teaching, 8(1), 50-61 \\ doi: http://dx.doi.org/10.24235/eduma.v8i2.5386
}

Nur Aqidah¹, Edi Prio Baskoro*2, Budi Manfaat ${ }^{3}$

1,2,3 Department of Mathemtics Education, Syekh Nurjati Islamic State University ,Cirebon, Indonesia

"Corresponding author: Department of Mathemtics Education, Syekh Nurjati Islamic State University ,Cirebon, Indonesia:

Article history:

Received: 10 31, 2019

Accepted: 12 05. 2019

Published: 12 06, 2019

Copyright (C) 2019 by author (s) and EduMa: Mathematics Education Learning and Teaching under the Creative Commons Attribution-ShareAlike 4.0 International License.

\begin{abstract}
Development of Mathematical Learning Test For Student Groups With Linguistic Intelligence. This research is motivated by the availability of mathematical learning outcomes test instruments that are in accordance with the intelligence of students are inadequate. Therefore this study aims to develop the necessary tests. The test development follows the model proposed by Djemari Mardapi, which starts from the preparation of test specifications, writing test questions, testing the test, refining the test and assembling the test in full. Learning outcomes indicators refer to the syllabus in the 2013 curriculum and combine it with indicators of linguistic intelligence which then produce specific questions for groups of students with linguistic intelligence. The results of the field trials show that the test items developed have the ideal differentiation and difficulty level. The results of the application of the test on 27 students with linguistic intelligence showed that the mathematics learning outcomes of students of class VIII linguistic intelligence in SMP Negeri 7 Cirebon had reached KKM of $70.37 \%$. Of the 27 students there were 3 students $(11.11 \%)$ included in the less category, 5 students $(18.52 \%)$ which included enough categories, 15 students $(55.56 \%)$ which included good categories, and 4 students $(14.81 \%)$ which included very good categories. From the results of the research, it was found that dominant students with linguistic intelligence who were given tests according to linguistic intelligence tended to obtain better mathematics learning outcomes than students with other intelligences who were given similar tests.
\end{abstract}

Keyword s :

Learning Outcomes Test, Intelligence, Linguistic 


\section{INTRODUCTION}

Based on the theory of multiple intelligences proposed by Gardner (1983), in fact each student has various types of intelligence, only he has a tendency to certain types of intelligence. This tendency makes students feel comfortable and will provide an optimal response if given a stimulus that is in accordance with the tendency.

One way that can be done to find out the results achieved by students after carrying out learning activities is to give a test. In general, the tests used to measure student learning outcomes are generic or are generally used for all students with a variety of intelligence to find out their learning outcomes in accordance with the learning objectives that have been formulated. This is as said by Hanafi (2019) that in the application in the field every educational institution in Indonesia majority restricts the intelligence of students by only limiting certain intelligence. Ideally, one good test must be fair. That is, there is no group of students who feel disadvantaged or disadvantaged. Fair also means placing something in its place, which in this case places a test with certain characteristics in a certain group of students according to the different types of intelligence. If this is done it will provide benefits and positive contributions to the learning outcomes of students, because the characteristics of the test given in accordance with the type of intelligence.

In general, mathematics learning achievement tests are made directly in the form of commands using mathematical symbols. Meanwhile, questions with such a form might be suitable if given to students with mathematical logical intelligence, but not necessarily suitable or even not suitable if given to students with other intelligences including one group of students with linguistic intelligence. This shows that there are restrictions on educational programs that focus on certain intelligences. Restrictions on educational programs that focus on certain intelligence in greater numbers can minimize the importance of other forms of knowledge (Hanafi, 2019).

The best way to give tests to students with a tendency to the type of linguistic intelligence is to invite them to talk, provide reading material, recordings, provide a means for writing as well as everything related to listening, saying and seeing words. However, in reality the characteristics of the test by paying attention to the type of linguistic intelligence of students to find out the learning outcomes of students with this type of linguistic intelligence are still rarely found. Based on research conducted by Irvaniyah (2014) there is no difference in the average linguistic intelligence between male and female students. Therefore, researchers are interested in developing a test instrument for groups of students with linguistic intelligence to find out student learning outcomes and assist teachers in achieving student learning outcomes in accordance with expected goals.

Based on the background that has been described, it is necessary to conduct research on the development of mathematics learning achievement tests for groups of students with linguistic intelligence. Based on the description above, the formulation of the problem in this study is how the construct of the mathematics learning achievement test 
instrument for groups of students with linguistic intelligence.

The elaboration of the formulation of the problem is as follows:

1. How is the instrument of mathematics learning outcomes test lattice for groups of students with linguistic intelligence?

2. How is the quality of the mathematics learning achievement test instrument (validity, reliability, level of difficulty and differentiation) for groups of students with linguistic intelligence?

3. How is the learning outcomes of students with linguistic intelligence accessed using the developed test instruments?.

\section{LITERATURE REVIEW}

Linguistic Intelligence

Intelligence is the ability possessed by someone which includes knowledge, skills and expertise to solve the problem (Rofiah, 2016). While Ali (2009) argues that intelligence or intelligence is a dual ability to be able to realize the various possibilities that are influenced by motivation and relevant educational experiences that exist in a person. So, it can be interpreted that intelligence is a person's ability to find and solve problems that are influenced by the experience they have.

One of the intelligences present in humans is linguistic intelligence. Linguistic intelligence is one of the intelligence that is and is owned by humans. Linguistic intelligence is related to words and language. Linguistic-verbal intelligence or known as smart words is the ability to use language both oral and written appropriately and accurately
(Yaumi \& Nurdin, 2016). Linguistic intelligence is an ability that is very sensitive to the voice, rhythm, and meaning of words and a strong desire to express in written form (Masrurah, 2014: 310). People who have linguistic intelligence tend to use words in thinking and solving problems.

This intelligence has four skills, namely listening, reading, writing and speaking (Yaumi \& Nurdin, 2016). Meanwhile, according to Lucy (2016), this intelligence includes the ability to speak, write, tell or listen, analyze grammar, understand words and feel the meaning of words, remember information and convince others of their opinions. Children who have linguistic intelligence are generally able to read and understand what is read, able to listen well and respond in verbal communication, can write words and speak effectively, have a vast vocabulary and like poetry or pun. This intelligence includes the ability to handle language structures (syntax), sound (phonology), and meaning (semantics) with the dominant competency being the ability to think in words (Lucy, 2016). Linguistic intelligence has indicators of ability to hear, speak, write and read (Chatib, 2019).

\section{Characteristics of Linguistic Intelligence}

Gunawan (2011) argues that people with well-developed linguistic intelligence have the following characteristics: 1) Able to listen and respond to spoken words and a verbal communication. 2) Able to imitate sounds, learn languages, and be able to read and write the work of others. 3) Able to learn through hearing, reading material, writing, and through discussion or debate. 4) Able to listen effectively and understand and remember what has been 
heard. 5) Able to read and understand what is read. 6) Able to speak and write effectively. 7) Able to learn foreign languages. 8) Able to improve language skills used for daily communication. 9) Interested in journalism work, debate, talk, write, or tell a story or make improvements to the paper. 10) Having the ability to tell and enjoy humor.

Characteristics of students who have linguistic intelligence in this study as the opinions said by Gunawan (2011) include being able to listen and respond to spoken words, being able to learn through hearing, reading material, writing and through discussion and being able to read and understand what which is read. This is indicated by the tendency of students who prefer to listen when the teacher explains and summarizes the material or notes the material being studied / explained by the teacher. In addition they like to discuss in groups and express their opinions through discussions and presentations.

\section{Mathematics Learning Outcomes Test}

The test is an inseparable part of the learning process. The test has its own role in determining student learning outcomes to determine the extent of their ability to receive and understand the subject matter delivered by the teacher.

According to Supriadie (2012) the test is an assessment tool that is developed systematically in an effort to measure a number of behaviors or qualifications that are expected to be achieved. Meanwhile according to Sudijono (2012: 67) the test is a way (which can be used) or procedures (which need to be taken) in the framework of measurement and assessment in the field of education, in the form of assignments or a series of tasks (both in the form of questions (which must be answered), or commands (which must be done) by the testee, so that (on the basis of data obtained from the results of these measurements) a value that represents the behavior or achievement of the testee can be generated, which values can be compared with the values achieved by other testees or compared to certain standard values.

Learning outcomes are changes in student behavior achieved after implementing the learning process in which behavioral changes include cognitive, affective, and psychomotor aspects (Harjoko, 2014). Meanwhile, according to Sjukur (2012) learning outcomes are abilities obtained by individuals after the learning process takes place that can affect behavior changes both knowledge, understanding, attitudes and skills of students so that it becomes better than before.

As according to Sinar (2018) learning outcomes are achievements achieved after students complete a number of subject matter. So it can be said that learning outcomes are everything both the skills and experience students have after conducting the teaching and learning process. While the learning outcomes test is an instrument used to determine student progress after conducting the learning process.

According to Uno \& Squared (2009) mathematics is a field of science that is a tool of thought, communication, a tool to solve various practical problems, the elements of which are logic and intuition, analysis and construction, generality and individuality, and have branches including arithmetic, algebra, geometry, and analysis. 
Mathematics is not only aimed at being able to count alone, but rather training students in solving problems that exist in everyday life by using mathematical concepts. This is as said by Jusmiati (2017) that the purpose of learning mathematics is not just counting but also required to be better able to deal with various problems in life, both regarding mathematics itself and problems in other sciences, as well as being demanded by a scientific discipline high so that when you have understood the basic mathematical concepts can be applied in everyday life.

Regarding mathematics learning in schools, Okuba (2007) explains that one of the characteristics of school mathematics is that the content of learning in each class is based on what children have learned in the previous year or earlier in the same year, which involves the initial year of learning, consequently Sufficient understanding of content and procedures is very important for students to carry out further problem solving activities (Sriyanto, 2017: 51).

So from the above explanation it can be concluded that the mathematics learning achievement test is a measuring tool used to determine student achievement towards learning objectives that have been planned after going through the process of learning mathematics.

\section{METHODS}

This study aims to produce mathematics learning achievement test instruments for groups of students with linguistic intelligence. From these objectives, this research is classified as research development or Research and Development (R\&D). The development model in this study refers to the development model proposed by Djemari Mardapi.

The test that was developed in this research is a breakdown test on the material on the flat side chamber. The selection of the test form in the form of description is done on the consideration that the description test is able to measure the ability of the students to complete the given test.

The research subjects were students of class VIII A, VIII B, VIII E, VIII $F$ and VIII G of SMP Negeri 7 Cirebon who tend to have linguistic intelligence. The selection of research subjects is done by giving intelligence identification sheets adopted from books written by Chomaria (2014).

\section{RESULT AND DISCUSSION}

In the design stage of the test instrument for learning outcomes for groups of students with linguistic intelligence is carried out through several stages, namely starting from compiling the test specifications, writing test questions to interpreting test results. In this study, the test that was developed was for the purpose of formative tests namely to measure the success/achievement of students who have a dominant linguistic intelligence in solving mathematical test questions that were developed. The test lattice is arranged based on learning achievement test indicators that refer to the syllabus in the 2013 curriculum and combines them with indicators of linguistic intelligence which then produces specific question forms for groups of students with linguistic intelligence. The form of test developed is a description test on the basis of the consideration that the 
description test is able to measure the ability of students to complete the given test. The length of the test items made by researchers on average less than half a page. Based on the number of questions and the level of difficulty of the test questions made, researchers set the length of the test for 2 hours of study or about 80 minutes. The questions developed consisted of 5 designs with a total of 10 questions. The developed test instrument grid can be seen in Table 1 .

Tabel .1

Mathematics Learning Outcomes Test Grid for groups of Students with Linguistic Intelligence

\begin{tabular}{|c|c|c|c|}
\hline $\begin{array}{l}\text { Dimensio } \\
\mathrm{n} / \text { Aspect }\end{array}$ & $\begin{array}{c}\text { Indicator of Achievement } \\
\text { of Learning Outcomes }\end{array}$ & Design of Item Number & $\begin{array}{c}\text { Item } \\
\text { Problem }\end{array}$ \\
\hline Cognitive & $\begin{array}{l}\text { Students can create as } \\
\text { many problems as possible } \\
\text { related to surface area or } \\
\text { volume of flat side spaces } \\
\text { with good, correct verbal } \\
\text { language. }\end{array}$ & $\begin{array}{l}\text { Desain A } \\
\text { Stimulus questions are presented in the } \\
\text { form of images that illustrate the } \\
\text { construction of a particular space. Students } \\
\text { are asked to make as many interesting } \\
\text { questions as possible related to the shapes } \\
\text { presented using good verbal language. } \\
\text { Desain B }\end{array}$ & 1 \\
\hline $\begin{array}{l}\text { Psychomo } \\
\text { tor }\end{array}$ & $\begin{array}{l}\text { Students can sketch / } \\
\text { draw, classify and identify } \\
\text { the elements / } \\
\text { characteristics of a flat } \\
\text { sided space. }\end{array}$ & $\begin{array}{l}\text { Stimulus questions are presented in the } \\
\text { form of verbal descriptions about a flat side } \\
\text { chamber arranged in a stack. Students are } \\
\text { asked to draw drawings / sketches of the } \\
\text { description presented, classify and identify } \\
\text { the shapes by representing their } \\
\text { characteristics / characteristics as much as } \\
\text { possible }\end{array}$ & $\begin{array}{l}\text { 2.a, } 2 . b, \\
\quad 3\end{array}$ \\
\hline & $\begin{array}{l}\text { Students can make webs } \\
\text { to build flat side spaces. }\end{array}$ & $\begin{array}{l}\text { Desain C } \\
\text { Stimulus questions are presented in the } \\
\text { form of a brief narrative about an object in } \\
\text { the form of a flat side space and is } \\
\text { equipped with images. Students are asked } \\
\text { to be creative in making as many networks } \\
\text { as possible. }\end{array}$ & $4 a, 4 b$ \\
\hline Cognitive & $\begin{array}{l}\text { Students can solve } \\
\text { everyday problems related } \\
\text { to surface area and } \\
\text { volume of flat side spaces. }\end{array}$ & $\begin{array}{l}\text { Desain D } \\
\text { Stimulus questions are presented in the } \\
\text { form of a brief narrative about a daily } \\
\text { problem that is equipped with a picture of } \\
\text { a flat sided space. Students are asked to } \\
\text { solve these problems by using the concepts } \\
\text { of surface area and volume of flat side } \\
\text { spaces. } \\
\text { Desain E } \\
\text { Stimulus questions are presented in the } \\
\text { form of contextual narratives that are } \\
\text { complemented by certain information } \\
\text { related to the construction of flat side } \\
\text { spaces. Students are asked to solve } \\
\text { problems related to surface area and } \\
\text { volume of flat side spaces. }\end{array}$ & $8,9,10$ \\
\hline
\end{tabular}




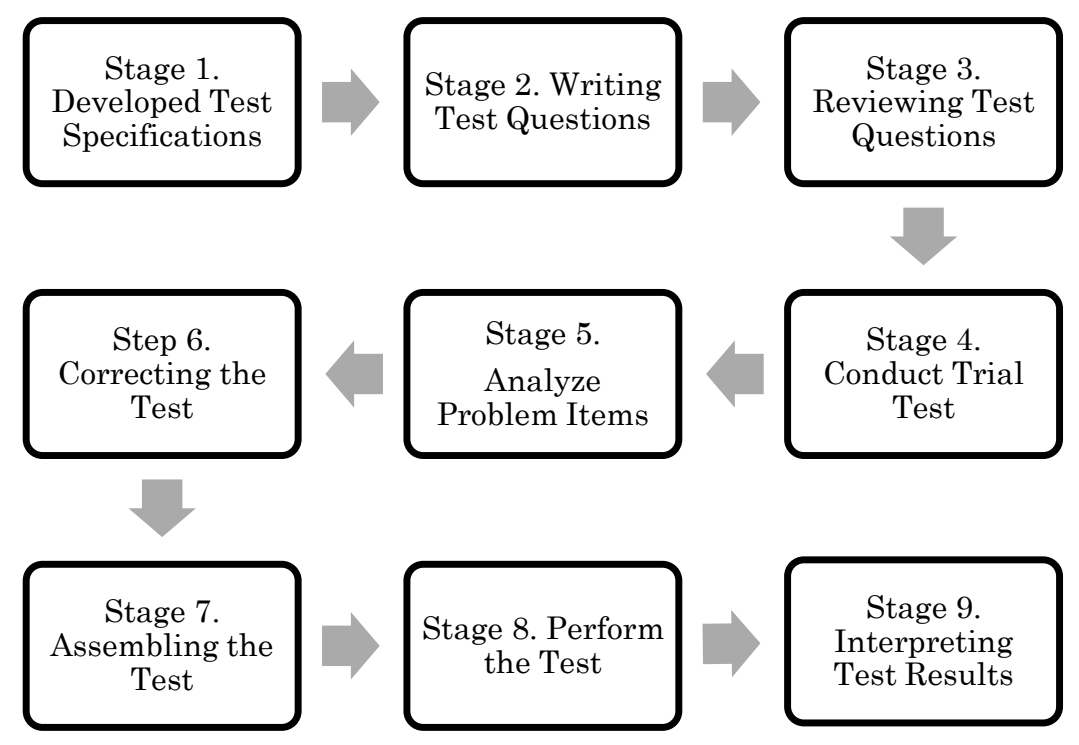

Figure 1. Flow Test Development

The sample questions developed based on the grid that have been made are as follows:

Design A - Problem number 1

Look at the picture below!

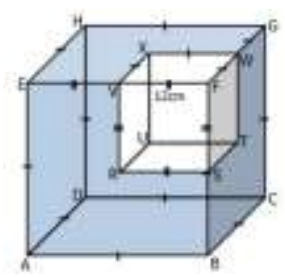

Ask as many interesting problems / questions as you can with the above building using good, correct verbal language!

Design B - Problem number 2

Hani has a birthday cake that is formed from two shapes that are arranged stacked upwards. Both shapes have the same shape and size on the base. Build the bottom of the box with the size of the sides the same length, while the upper part is shaped like a pyramid (one of the historical buildings in Egypt). The cake has a height of $32 \mathrm{~cm}$ with a height ratio of the box and pyramid height is 3: 1 . Hani wants to cut the cake into pieces. First, Hani cut the cake into two pieces so that a box and pyramid shape were obtained. In a box shape, Hani cut it into two equal parts without changing the shape and size of the base. Then each piece of cake is placed on a red and blue plate by Hani. On a red plate, Hani cuts it into two equal parts in the direction perpendicular to the length of the base. While on a blue plate, Hani cut it into two equal parts to form an angle of 90 at one corner.

Design C - Problem number 4

Luqman and Labib have a cardboard shaped like the one below.
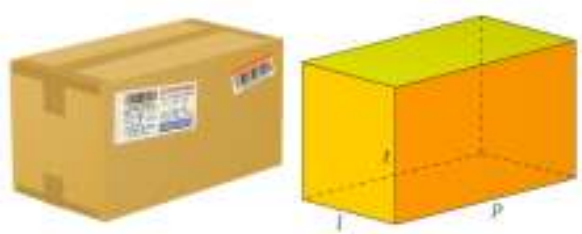

Luqman and Labib wanted to be creative in turning the cardboard into a flat shape by cutting it right on the ribs. Even so, the shape that is formed is still in one unified whole and if connected again it will form a cardboard like the original shape.

a. How many possible forms can Luqman and Labib have made?

What forms might Luqman and Labib have made? 
Design D - Problem number 6

Dina has an aquarium like the picture below.

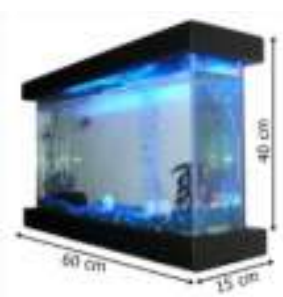

The aquarium is filled with as much water as a part. If Dina wants to remove part of the total water in the aquarium, what is the volume of water in the aquarium?
Design E - Problem number 8

On Sunday, April 21, 2019 one of Mira's friends, Linda, had a birthday. Mira was about to make some gifts for him. There are cube-shaped gifts, pyramid and triangular prisms. If the three gifts have a base of the same size, which is $10 \mathrm{~cm}$ and the height of the gifts is $12 \mathrm{~cm}$ except for the cube and the height of the triangle's side on the quadrilateral shape is $13 \mathrm{~cm}$. What is the minimum wrapping paper needed by Mira if the three gifts are packaged separately?

The scoring criteria are carried out using a range of 1 - 5. The following is a general description of the criteria for extracting test instruments for mathematics learning outcomes developed.

Table 2

Criteria for Calculating Mathematics Learning Outcomes Tests for Groups of Students with Linguistic Intelligence

\begin{tabular}{llc}
\hline No & \multicolumn{1}{c}{ Criteria } & Scor \\
\hline 1 & & If students don't give answers at all. \\
\hline 2 & If students try to give a step completion, but not finished. & 1 \\
3 & If students try to give a step completion, but the answer is wrong. & 3 \\
4 & $\begin{array}{l}\text { If students are able to complete the command / question posed using the } \\
\text { appropriate completion procedure but still contains some errors and the } \\
\text { answers are correct. }\end{array}$ & 4 \\
& $\begin{array}{l}\text { If students are able to complete the questions posed with appropriate and } \\
\text { systematic settlement procedures with the results of correct answers }\end{array}$ & 5 \\
&
\end{tabular}

One of the steps to produce a good test is to examine the test questions. Tests that have been prepared, submitted to the experts (Expert Judgment) for review. This study is conducted to determine its validity. The results of the validity by the expert team showed that the test questions developed had good content validity with a CVR value of 1 .

After the test instrument is made and declared valid by experts, the next step is to conduct a trial. The instrument testing was conducted on 27 students of class VIII of SMP Negeri 7 Cirebon who had dominant linguistic intelligence and 
who had dominant kinesthetic intelligence. This is done to determine the effectiveness and suitability of the developed test. Based on the results of tests on students with linguistic intelligence, the reliability value is indicated by the Alpha Cronbach coefficient of 0.73 with high interpretation. As for the level of difficulty obtained an average index of difficulty of 0.69 with the medium category and the distinguishing power of each item developed is included in the ideal category.

Mathematics learning outcomes data for groups of students who have linguistic and kinesthetic intelligence are obtained through instruments that have been developed. From the mathematics learning outcomes obtained through the results of the test instruments, the authors classify them in Table 3 and Table 4 .

Table 3

Grouping of Mathematics Learning Outcomes Test Scores

Linguistic Intelligence Students

\begin{tabular}{ccccc}
\hline \multirow{2}{*}{ No. } & \multirow{2}{*}{ Score } & Category & \multicolumn{2}{c}{ Kinesthetic Intelligence } \\
Frequency & Percentage \\
\hline 1 & $80-100$ & Very Good & 4 & $14,81 \%$ \\
2 & $65-79$ & Good & 15 & $55,56 \%$ \\
3 & $55-64$ & Enough & 5 & $18,52 \%$ \\
4 & $41-54$ & Less & 3 & $11,11 \%$ \\
5 & $0-40$ & Very Less & 0 & $0,00 \%$ \\
& & & 27 & $100 \%$ \\
\hline
\end{tabular}

Tabel 4

Grouping of Mathematics Learning Test Results

Kinesthetic Intelligence Students

\begin{tabular}{ccccc}
\hline \multirow{2}{*}{ No. } & \multirow{2}{*}{ Score } & Category & \multicolumn{2}{c}{ Kinesthetic Intelligence } \\
& & Frequency & Percentage \\
\hline 1 & $80-100$ & Very Good & 0 & $0,00 \%$ \\
2 & $65-79$ & Good & 0 & $0,00 \%$ \\
3 & $55-64$ & Enough & 1 & $3,70 \%$ \\
4 & $41-54$ & Less & 19 & $70,37 \%$ \\
5 & $0-40$ & Very Less & 7 & $25,93 \%$ \\
& & & 27 & $100 \%$ \\
\hline
\end{tabular}

By looking at the Minimum Mastery Criteria (KKM) for mathematics in SMP Negeri 7, Cirebon, from the results of the mathematics learning achievement test instrument developed for students with linguistic intelligence on the material of flat side space there were 19 students or $70.37 \%$ had reach KKM. However, student learning outcomes with kinesthetic intelligence based on test instruments developed did not have students or at $0 \%$ who achieved KKM. That is, as a whole, the basic mathematical abilities of the research sample based on the same level of ability appear to differ significantly between students who are dominantly linguistic 
with students who are predominantly kinesthetic intelligence.

Based on data analysis of student learning outcomes with linguistic intelligence it can be stated that from 27 students who were used as research samples, the highest mathematics learning outcomes were 88 and the lowest was 42. Based on data analysis and categorizing mathematics learning outcomes of students with linguistic intelligence grade VIII of SMP Negeri 7 Cirebon shows that $55.56 \%$ are in the good category. This shows that students who have dominant linguistic intelligence have the ability to solve good math problems.

Linguistic intelligence is one of eight types of intelligence possessed by individuals. This is based on the theory of Multiple Intelligences proposed by Gardner (1983). Someone who has high linguistic intelligence has the ability to digest and examine words both oral and written well. This is consistent with the results of research conducted on students with linguistic intelligence who are given tests with characteristics of test items that have been adjusted to the characteristics of their intelligence, namely linguistic intelligence. The results showed that more than $70 \%$ of students received a complete grade or achieved KKM. This means that the test items developed by researchers are considered feasible and effective.

The results of this study can be used as a reference for developing innovative learning outcomes tests, namely learning outcomes tests that are appropriate to the type of student intelligence. From the research results it is known that students with dominant linguistic intelligence who are given tests according to linguistic intelligence tend to get better mathematics learning outcomes than students with other intelligence who are given tests with characteristics for linguistic students. This can be used as a reference in an effort to improve student learning outcomes and if this is done by most teachers, then in the end, student mathematics learning outcomes as a whole will increase.

\section{CONCLUSION AND IMPLICATION}

\section{Conclusion}

Based on the results of previous studies and discussions, it can be concluded as follows: 1) The test grid is made based on discussions conducted by researchers with supervisors. In the test lattice contains two measuring dimensions, namely cognitive and psychomotor. Indicators of learning outcomes are obtained from the syllabus in the 2013 curriculum and combine them with indicators of linguistic intelligence which then produce specific question forms for groups of students with linguistic intelligence. 2) The contents of the test have been declared valid according to the considerations of several experts (Expert Judgment). The trial results also show that the test has high reliability. The results of the analysis of the reliability of the test are shown by Cronbach's Alpha coefficient of 0.73. This can be interpreted that the mathematics learning achievement test instrument for groups of students with developed linguistic intelligence is appropriate to be used as a further evaluation tool. The results of the analysis of the difficulty level obtained 1 item in the easy category and 9 items in the medium category. While the results of the analysis of the distinguishing power of items obtained 4 items with enough categories, namely 
items number 1, 6, 8 and 10, and 6 items with good categories, namely items number 2, 3, 4, 5, 7 and 9 Thus the developed test instruments meet the criteria for good quality test instruments. 3) Based on the results of testing the application of tests on 27 students who have linguistic intelligence shows that the learning outcomes of mathematics students with linguistic intelligence in class VIII of SMP Negeri 7 Cirebon have reached KKM of $70.37 \%$. Of the 27 students there were 3 students (11.11\%) who were in the poor category, 5 students $(18.52 \%)$ were in the moderate category, 15 students (55.56\%) were in the good category, and 4 students (14, 81\%) which is in the very good category.

\section{Suggestion}

Suggestions for further research that will develop mathematics learning achievement tests for groups of students with linguistic intelligence are as follows: 1) It is recommended that development of mathematics learning outcomes tests for groups of students with linguistic intelligence return in order to obtain better instruments. 2) The number of questions to be tested should be reproduced and adjusted to the time and condition of participants to develop further instruments. 3) It is better for the next research questions to be developed based on the dominant type of student intelligence

\section{REFERENCES}

Ali, M. (2009). Pendidikan untuk Pembangunan Nasional. Jakarta: Grasindo.

Chatib, M. (2012). Orangtuanya Manusia: Melejitkan Potensi dan Kecerdasan dengan Menghargai Fitrah Setiap Anak. Bandung: PT Mizan Pustaka.

Chomaria, N. (2014). Tes Kepribadian Remaja Muslim. Surakarta: al-Qudwah Publishing.
Gardner, H. (1983). Frames of Mind: The Theory Of Multiple Intelligence. New York: Basic Books.

Gunawan, A. W. (2011). Born to be a Genius. Jakarta: PT Gramedia Pustaka Utama.

Hanafi, M. Z. (2019). Implementasi Metode Sentra Dalam Pengembangan Kecerdasan Majemuk Anak Usia Dini. Yogyakarta: Deepublish.

Lucy, B. (2016). Panduan Praktis Tes Minat Bakat Anak. Jakarta: Penebar Plus.

Sinar. (2018). Metode Active Learning Upaya Peningkatan Keaktifan dan Hasil Belajar Siswa. Yogyakarta: Deepublish.

Sriyanto. (2017). Mengobarkan Api Matematika. Sukabumi: CV Jejak.

Sudijono, A. (2012). Pengantar Evaluasi Pendidikan (12th ed.). Jakarta: PT. Rajagrafindo Persada.

Supriadie, D. (2012). Komunikasi Pembelajaran (Pertama). Bandung: PT. Remaja Rosdakarya.

Uno, H., \& Kuadrat, M. (2009). Mengelola Kecerdasan dalam Pembelajaran (2nd ed.). Jakarta: Bumi Aksara.

Yaumi, M., \& Nurdin, I. (2016). Pembelajaran Berbasis Kecerdasan Jamak (Multiple Intelligencess. Jakarta: Prenadamedia Group.

Irvaniyah, I., \& Akbar, R. O. (2014). Analisis Kecerdasan Logis Matematis dan Kecerdasan Linguistik Siswa Berdasarkan Jenis Kelamin (Studi Kasus Pada Siswa Kelas XI IPA MA Mafatihul Huda). Eduma: Mathematics Education Learning and Teaching, 3(1), 138-159

Harjoko. (2014). Meningkatkan Hasil Belajar Matematika Melalui Penerapan Model Pembelajaran Kooperatif Tipe TGT (Teams Games Tournaments) Pada Siswa Kelas V SD N Kedungjambal 02 KAB. Sukoharjo Tahun Ajaran 2013/2014. Skripsi tidak diterbitkan Universitas negeri Yogyakarta

Jusmiati, D. (2018). Pengaruh pendekatan pembelajaran matematika realistik terhadap kemampuan berpikir kreatif pada pokok bahasan lingkaran kelas viii Mts. Al-Ittihadiyah (Mamiyai) kec. Medan Area (Doctoral dissertation, Universitas Islam Negeri Sumatera Utara).

Masrurah, F. (2014). Kecerdasan VerbalLinguistik Anak Melalui Pendekatan 
Beyond Centers and Circle Time (Bcct). Lisan al-Hal: Jurnal Pengembangan Pemikiran dan Kebudayaan, 8(2), 305-334.

Rofiah, N. H. (2016).Menerapkan Multiple Intelligences dalam Pembelajaran di
Sekolah Dasar. Dinamika Pendidikan Dasar, 8(1), 69-79

Sjukur, S. . (2012). Pengaruh Blended Learning Terhadap Motivasi Belajar dan Hasil Belajar Siswa Tingkat SMK. Pendidikan Vokasi, 2(3), 368378 